\title{
Pengaruh Metode Struktural Analitik Sintetik (SAS) Terhadap Kemampuan Membaca Permulaan Pada Anak Kelompok B
}

\author{
Luh Neli Antari ${ }^{1}$, I Made Tegeh ${ }^{1}$, Putu Rahayu Ujianti ${ }^{2}$ \\ 1,2Jurusan Pendidikan Dasar \\ ${ }^{1}$ Jurusan IPPB \\ Universitas Pendidikan Ganesha \\ Singaraja, Indonesia \\ e-mail: luhneliantari@gmail.com
}

\begin{abstract}
Abstrak
Permasalahan dalam penelitian ini adalah kemampuan membaca permulaan anak pada kelompok B di Gugus VII Kecamatan Buleleng Kabupaten Buleleng tahun pelajaran 2018/2019. Penelitian ini bertujuan untuk mengetahui pengaruh yang signifikan metode SAS (Struktural Analitik Sintetik) terhadap kemampuan membaca permulaan pada anak kelompok B Taman Kanak-kanak Gugus IV Kecamatan Buleleng tahun pelajaran 2018/2019. Jenis penelitian ini merupakan jenis penelitian eksperimen semu (quasi experiment). Populasi dalam penelitian ini adalah seluruh anak kelompok B di Gugus IV Kecamatan Buleleng. Sampel dalam penelitian ini yaitu TK Cudhacrama Singaraja yang berjumlah 20 anak dan TK Santi Kumara Singaraja yang berjumlah 15 anak. Data kemampuan membaca permulaan anak dikumpulkan dengan menggunakan teknik observasi dan rubrik. Data yang diperoleh dianalisis dengan menggunakan statistik deskriptif dan statistik inferensial yaitu uji-t. Hasil penelitian menunjukkan bahwa terdapat perbedaan kemampuan membaca permulaan yang menggunakan metode SAS (Struktural Analitik Sintetik) dengan yang tidak menggunakan metode SAS (Struktural Analitik Sintetik) dengan thitung $=18,74$ dan tabel dengan $d k=\left(n_{1}+n_{2}-2\right)=33$ dengan taraf signifikansi $5 \%=2,034$ Dengan demikian thitung $>$ ttabel $=18,74>2,034$, maka $\mathrm{H}_{0}$ ditolak dan $\mathrm{H}_{\mathrm{A}}$ diterima. Jadi, dapat disimpulkan bahwa terdapat pengaruh yang signifikan metode Struktural Analitik Sintetik (SAS) terhadap kemampuan membaca permulaan pada anak. Hal ini dapat dilihat dari skor rata-rata anak yang menggunakan metode SAS yaitu 55,75 dan skor rata-rata anak yang tidak menggunakan metode SAS yaitu 31,18 . Penerapan metode SAS dalam proses pembelajaran digunakan untuk meningkatkan kemampuan membaca permulaan pada anak dalam mengatasi kendala-kendala dalam proses pembelajaran di kelas.
\end{abstract}

Kata-kata Kunci: Metode SAS, Kemampuan, Membaca Permulaan

\begin{abstract}
The problem in this study was the beginning reading ability of group B children in Cluster VII Buleleng District, Buleleng Regency in academic year 2018/2019. This study aimed at determining the significant effect of SAS (Synthetic Structural Analysis) method on the ability to read early in group B Kindergarten children, Cluster IV District of Buleleng in academic year 2018/2019. This type of research is a quasi-experiment. The population in this study were all of children from group B in Cluster IV District of Buleleng. The sample in this study were 20 students of TK Cudha Crama Singaraja and 15 students of TK Santi Kumara Singaraja. The technique used in collecting the data were observation and rubric. The data were analyzed by using descriptive statistics and inferential statistics, named the t-test. The results showed that there were differences in the initial reading ability using the SAS (Synthetic Analytical Structural) method with those who did not using the SAS method (Synthetic Structural Analysis) with $t$ count $=18.74$ and $t$ table with $d k=(n 1+n 2-2)=33$ with significance level of $5 \%=2.034$ Thus tcount $>t$ table $=18.74>2.034$, then $\mathrm{HO}$ is rejected and $\mathrm{HA}$ is accepted. So, it can be concluded that there is a significant effect of the Synthetic Analytical Structural (SAS) method on the beginning reading ability of children group. This can be seen from the average score of children using the SAS method, which is 55.75 and the average score of children who do not use the SAS method is 31.18 . The application of the SAS method in the learning process is used to improve the children beginning reading ability in faced any problem in learning process in the classroom.
\end{abstract}

Keywords: Skill, Early Reading, SAS Method 


\section{PENDAHULUAN}

Anak usia dini menurut NAEYC (National Association for The Educational of Young Children) dalam Ambara (2015:1) adalah anak yang berada pada rentang usia 0 - 8 tahun dan mampu berkembang secara pesat melalui lingkungan sekitarnya. Pada periode ini dikenal dengan istilah masa keemasan (golden age). Aspek perkembangan anak meliputi perkembangan kognitif, bahasa, fisik-motorik, moral, sosial-emosional dan seni. Catron dan Allen (dalam Sujiono, 2009) menyatakan terdapat 6 (enam) aspek perkembangan anak usia dini, yaitu kesadaran personal, kesehatan emosional, sosialisasi, komunikasi, kognisi, dan keterampilan motorik yang sangat penting dan harus dipertimbangkan sebagai fungsi interaksi. Aspek tersebut perlu untuk dikembangkan secara optimal sebagai landasan perkembangan anak pada tahap selanjutnya, salah satunya pada aspek perkembangan bahasa anak. Kemampuan bahasa dipelajari dan diperoleh anak usia dini secara alamiah untuk beradaptasi dengan lingkungannya.

Menurut Lerner (dalam Mutiah, 2010:165) menyatakan bahwa dasar utama perkembangan bahasa adalah melalui pengalaman-pengalaman berkomunikasi yang kaya. Pengalamanpengalaman yang kaya akan menunjang faktor-faktor bahasa antara lain; mendengarkan, berbicara, membaca dan menulis. Dengan demikian perkembangan aspek berbahasa ini penting untuk distimulasi, terlebih lagi dalam hal membaca. Meskipun pelajaran membaca formal biasanya sering di ajarkan di kelas satu SD, namun anak usia dini di Taman Kanak-kanak sudah memiliki kesiapan dalam mengembangkan keterampilan membacanya. Membaca pada anak usia dini tidak sama dengan kemampuan membaca usia dewasa. Membaca pada anak usia dini lebih dikenal dengan membaca permulaan yang berada pada tahap awal proses menerjemahkan simbol tulis kedalam bunyi (Tjoe, 2013:9). Papalia (2008:248) mengatakan bahwa "Mayoritas bayi sangat menyukai bacaan cerita, nada pembacaan yang dilakukan oleh orangtua atau pengasuh dan cara membacakan ketika bercerita dapat mempengaruhi seberapa baik anak berbicara, yang dapat mempengaruhi kemampuan membacanya". Dengan demikian kemampuan membaca permulaan pada anak usia dini terbentuk ketika usia anak masih sangat muda. Pengajaran membaca pada anak usia dini menekankan pada kemampuan dasar membaca dan dimulai dengan cara yang paling mudah, hal tersebut senada dengan yang dikatakan Steinberg (dalam Susanto, 2011:83) membaca dini ialah membaca yang diajarkan secara terprogram kepada anak prasekolah. Zubaidah (dalam Pertiwi, 2016:760) juga menyatakan bahwa "membaca permulaan atau membaca awal lebih menekankan pada pengenalan dan pengucapan lambang-lambang bunyi yang berupa huruf, kata dan kalimat dalam bentuk sederhana".

Anak usia dini berada pada tahap pra-operasional dimana mereka belajar dengan melihat benda-benda konkret dan mulai mempresentasikan ulang dunia dengan kata-kata, cerita dan gambar (Jahja, 2011). Berdasarkan hal tersebut maka diperlukan sarana dan metode yang sesuai untuk mengembangkan kemampuan membaca permulaan anak. Pengenalan membaca permulaan pada anak juga harus dilakukan dengan cara yang menarik dan menyenangkan, tujuannya agar pesan yang ingin disampaikan oleh guru dapat ditangkap atau dicerna dengan mudah oleh anak. Hal tersebut mengacu pada prinsip belajar anak usia dini yaitu prinsip belajar melalui bermain. Berdasarkan hal tersebut maka kemampuan membaca permulaan anak usia dini lebih menekankan pada pengenalan lambang-lambang bunyi dan bertujuan agar anak memiliki kemampuan membaca untuk menyiapkan anak memasuki sekolah dasar.

Berdasarkan hasil observasi yang dilakukan di TK Widya Kumara Sari, TK Santi Kumara, TK Purwa Widya Dhikrama, TK Nurul Mubin, TK Ganesha, TK Kumara Satya Dharma, TK Santo Rafael, TK Cudhacrama yang berada pada gugus IV Kecamatan Buleleng tahun pelajaran 2018/2019 pada tanggal 28 Januari 2019-02 Februari 2019 menunjukkan perkembangan kemampuan membaca permulaan anak pada kelompok B sudah dilaksanakan tetapi masih ada beberapa anak yang belum mampu menyebutkan kata dengan jelas dan ada beberapa anak yang belum mampu menggabungkan beberapa huruf menjadi sebuah kata serta kata menjadi kalimat sederhana. Sedangkan dari hasil wawancara dengan guru kelompok B pada Gugus IV Kecamatan Buleleng pada tanggal 02 Februari 2019-04 Februari 2019 juga mengungkapkan bahwa terdapat anak yang belum mampu menyebutkan simbol-simbol huruf yang dikenal, mengenal suara huruf awal dari nama benda-benda yang ada disekitarnya, menyebutkan kelompok gambar yang memiliki bunyi/huruf awal yang sama, memahami hubungan antara bunyi dan bentuk huruf, membaca nama 
sendiri, menuliskan nama sendiri, hal ini dilihat juga ketika pada proses kegiatan pembelajaran membaca permulaan anak ditemukan masih perlu dikembangkan secara optimal.

Hasil pengamatan ditemukan anak belum bisa menggabungkan beberapa huruf menjadi sebuah kata, sebagian besar kemampuan membaca permulaan anak seperti merangkai huruf menjadi suku kata, dan anak belum mampu mengucapkan kalimat dalam bentuk sederhana serta kurangnya penggunaan media atau metode pembelajaran yang lebih inovatif. Permasalahanpermasalahan tersebut akan berdampak kurang baik jika dibiarkan mengingat bahwa kemampuan membaca permulaan sangat penting bagi anak. Faktor penyebab dari permasalahan tersebut yang peneliti lihat bahwa dalam memberikan pembelajaran membaca permulaan guru lebih sering menggunakan metode ceramah dan lebih cenderung hanya memberikan instruksi kepada anak ketika proses belajar mengajar berlangsung. Metode pembelajaran yang digunakan oleh guru pada saat proses belajar mengajar berlangsung masih bersifat monoton dan terbatasnya menggunakan media yang menarik serta sebagian besar kegiatan pengembangan bahasa dalam membaca permulaan lebih sering menggunakan lembar kerja anak (LKA), buku tulis, papan tulis, dan jarang menggunakan media pembelajaran yang menarik bagi anak pada saat proses belajar mengajar di sekolah. Keterbatasan media serta kurangnya penerapan metode-metode dalam proses belajar mengajar akan berdampak terhadap daya tarik anak untuk mengikuti proses pembelajaran sehingga anak tidak memiliki semangat dan motivasi untuk belajar.

Persoalan membaca, menulis dan berhitung memang merupakan fenomena tersendiri. Kini menjadi semakin hangat dibicarakan para orang tua yang memiliki anak usia taman kanak-kanak (TK), mereka khawatir anak-anaknya tidak mampu mengikuti pelajaran ketika anak-anak mereka memasuki sekolah dasar apabila sejak awal belum dibekali kemampuan calistung (membaca, menulis dan berhitung). Kekhawatiran orang tua pun semakin mencuat ketika anak-anaknya belum bisa membaca menjelang memasuki sekolah dasar. Selama ini taman kanak-kanak diasumsikan sebagai tempat untuk mempersiapkan anak-anak memasuki masa sekolah yang dimulai dijenjang sekolah dasar. Pembelajaran membaca tidak diperkenankan ditingkat taman kanak-kanak, kecuali hanya pengenalan lambang-lambang huruf, itu pun dilakukan setelah anak-anak memasuki kelompok B. Akan tetapi, pada perkembangan terakhir fenomena tersebut menimbulkan sedikit masalah karena ternyata pembelajaran dikelas satu sekolah dasar sulit diikuti jika asumsinya anakanak lulusan TK belum mendapatkan pembelajaran membaca. Dengan demikian membaca permulaan pada anak kelompok B di taman kanak-kanak sangat penting untuk distimulasi.

Menstimulasi aspek perkembangan anak harus disesuaikan dengan karakteristik serta prinsipprinsip perkembangan anak. Anak membutuhkan bermacam-macam stimulasi yang proporsional, baik dalam kualitas maupun kuantitas, dan sesuai dengan tugas-tugas perkembangan anak. Menstimulasi perkembangan bahasa anak dalam kemampuan membaca permulaan yaitu dengan memberikan suasana belajar yang kondusif untuk anak, menciptakan lingkungan yang wajar, santai dan menyenangkan dalam kegiatan belajar mengajar, bebas dari tekanan dan hukuman, sehingga anak tidak merasa tertekan. Keadaan ini akan membuat anak belajar sambil bermain sehingga anak tidak merasa bosan dan jenuh ketika proses belajar mengajar.

Berdasarkan uraian di atas perlu adanya metode pembalajaran yang cocok dan sesuai untuk menstimulasi kemampuan membaca permulaan dalam pembelajaran dikelas. Salah satu alternatif yang dapat digunakan untuk menstimulasi perkembangan bahasa anak dalam kemampuan membaca permulaan adalah dengan menerapkan metode SAS (Struktural Analitik Sintetik). Penggunan metode SAS dalam pembelajaran membaca permulaan di taman kanak-kanak merupakan salah satu alternatif dalam membantu dan membimbing anak ke arah penemuan sendiri dengan menggunakan cerita yang disertai gambar. Pembelajaran membaca dengan metode ini terdiri dari pembelajaran dua tahap yakni menampilkan dan memperkenalkan sebuah kalimat utuh. Metode SAS merupakan salah satu jenis metode yang bisa digunakan untuk proses pembelajaran membaca bagi pemula Puspita, dkk., (dalam Aida, 2018). Sedangkan Kurniasih \& Berlin (2015) menyatakan metode ini dikhususkan untuk belajar membaca dan menulis permulaan di kelas SD pada kelas awal. Metode SAS bisa digunakan dalam pengajaran membaca permulaan pada anak usia dini dimana metode ini ditampilkan struktur kalimat secara utuh, kemudian dianalisis menjadi kata, suku kata dan huruf (Supriyadi dalam Aida, 2018).

Sani (2014:278) mengatakan bahwa "metode Struktural Analitik Sintetik (SAS) berpandangan bahwa pengamatan/penglihatan pertama setiap manusia adalah global atau bersifat menyeluruh". 
Oleh sebab itu, segala sesuatu yang akan diajarkan kepada peserta didik harus mulai ditunjukkan atau diperkenalkan strukturnya secara global. Metode SAS adalah suatu metode yang diawali secara keseluruhan yang kemudian dari keseluruhan itu dicari dan ditemukan bagian-bagian tertentu dan fungsi-fungsi bagian itu. Setelah mengenal bagian-bagian serta fungsinya kemudian dikembangkan pada struktur totalitas seperti seperti penglihatan semula. Oleh sebab itu, segala sesuatu yang akan diajarkan kepada peserta didik harus mulai ditunjukkan atau diperkenalkan strukturnya secara global. Setelah guru memandu peserta didik melakukan analisis untuk mencari atau menemukan bagian-bagian dari struktur global tersebut dan mengenal bagian-bagian serta fungsinya, peserta didik melakukan sintesis dengan mengembalikan bagian-bagian tersebut menjadi struktur totalitas/global seperti pada awalnya. Metode SAS (Struktural Analitik Sintetik) dapat merangsang anak didik untuk melibatkan diri secara aktif, karena anak didik selain mendengarkan, melafalkan dan mencatat juga mempergunakan media atau alat peraga yang menarik bagi anak.

Berdasarkan hal tersebut alternatif yang dapat digunakan untuk mengatasi permasalahan dalam menstimulasi perkembangan bahasa dalam membaca permulaan adalah metode SAS (Struktural Analitik Sintetik). Metode SAS (Struktural Analitik Sintetik) dipilih karena metode ini mampu digunakan untuk menstimulasi kemampuan membaca permulaan pada anak usia dini karena metode ini membantu menciptakan suasana pembelajaran yang nyaman dan menyenangkan serta dilaksanakan secara bertahap dan tidak menyimpang dari dunia dan kebutuhan anak. Penggunaan metode SAS dalam pembelajaran membaca permulaan di Taman Kanak-kanak merupakan salah satu alternatif dalam membantu atau membimbing anak ke arah penemuan sendiri dalam pengajaran membaca permulaan pada anak usia dini dimana metode ini ditampilkan struktur kalimat secara utuh, kemudian dianalisis menjadi kata, suku kata dan huruf dengan menggunakan bantuan alat peraga/media yang menarik dan inovatif untuk anak. Berdasarkan latar belakang di atas, maka peneliti tertarik mengkaji tentang "Pengaruh Metode SAS (Struktural Analitik Sintetik) terhadap Kemampuan Membaca Permulaan Pada Anak Kelompok B Taman Kanak-kanak Gugus IV Kecamatan Buleleng Tahun Pelajaran 2018/2019". Adapun tujuan yang ingin dicapai dalam penelitian ini yaitu mengetahui pengaruh yang signifikan metode SAS (Struktural Analitik Sintetik) terhadap kemampuan membaca permulaan pada anak kelompok B Taman Kanak-kanak Gugus IV Kecamatan Buleleng tahun pelajaran 2018/2019.

\section{METODE}

Penelitian ini bertempat di TK Gugus IV Kecamatan Buleleng Kabupaten Buleleng. Penelitian ini dilaksanakan pada rentang waktu semester genap tahun pelajaran 2018/2019, maka jenis penelitian yang digunakan dalam penelitian ini adalah jenis penelitian eksperimen semu (quasi experiment). Penelitian ini mengikuti desain penelitian kuasi eksperimen dengan rancangan nonequievalent control group design. Menurut Sugiyono (2017:72) penelitian eksperimen menentukan metode penelitian yang digunakan untuk mencari pengaruh perlakuan tertentu terhadap yang lain dalam kondisi yang terkendali. Pada dasarnya, rancangan ini hampir sama dengan pretest-posttest control group design. Dalam rancangan ini ada dua subjek. Satu kelompok mendapat perlakuan (kelompok eksperimen) dan satu kelompok sebagai kelompok kontrol. Keduanya memperoleh prates dan pascates.

Populasi dalam penelitian ini adalah seluruh anak kelompok B Gugus IV Kecamatan Buleleng. Data anak kelompok B di TK Gugus IV Kecamatan Buleleng pada tahun pelajaran 2018/2019. Sampel dalam penelitian ini menggunakan teknik simple random sampling. Simpel Random Sampling adalah teknik pengambilan sampel yang dilakukan secara acak tanpa memperhatikan strata yang ada dalam populasi itu Sugiyono (2017:63). Cara yang digunakan untuk menentukan sampel adalah masing-masing kelas diberi nomor urut, selanjutnya dipilih dua kelas secara random. Dua kelompok yang terpilih diundi kembali untuk menentukan kelas eksperimen dan kelas kontrol. Pada teknik ini, secara teoretis semua anggota dalam populasi mempunyai kesempatan yang sama untuk dipilih menjadi sampel, sehingga pengundian dilakukan dengan sistem pengambilan secara acak. Pada delapan taman kanak-kanak yang ada di Gugus IV Kecamatan Buleleng tahun pelajaran 2018/2019, dilakukan dua kali pengundian. Pengundian tahap pertama untuk memilih dua kelas yang dijadikan sampel penelitian. Kemudian, kedua kelas yang terpilih menjadi sampel diundi 
kembali untuk menentukan kelas eksperimen dan kelas kontrol. Sampel yang terpilih sebagai kelompok eksperimen adalah TK Cudhacrama Singaraja dan kelompok kontrol adalah TK Santi Kumara Singaraja.

Pengumpulan data dalam penelitian ini menggunakan dua metode yaitu observasi dan dua rubrik. Data yang diperlukan dalam penelitian ini adalah data dari hasil observasi dan post-test dari kelompok kontrol dan eksperimen. Observasi, menurut Nurkancana (dalam Agung, 2014:94) metode observasi adalah suatu cara yang digunakan untuk mengadakan penilaian dengan jalan mengadakan pengamatan secara langsung dan sistematis. Pada bagian ini peneliti akan mengobservasi permasalahan yang terlihat pada anak. Penelitian ini menggunakan validitas konstruksi (construct validity) dengan menggunakan pendapat para ahli (judgment experts). Hal ini dilakukan dikarenakan instrumen dikonstruksikan tentang aspek-aspek yang akan diukur dengan berlandaskan teori tertentu (Sugiyono, 2014:141). Setelah melakukan uji validiasi konstruk kemudian dilakukan uji validasi instrumen. Validasi instrumen menggunakan formula Gregory (Candiasa, 2011:96). Setelah melakukan uji ahli (judgment experts) dan memperbaiki instrument berdasarkan saran dari ahli, selanjutnya peneliti melakukan uji coba instrument. Uji coba dilaksanakan pada sampel diluar populasi diambil. Setelah data ditabulasikan, maka pengujian validitas isi dilakukan dengan analisis faktor, yaitu mengkorelasikan antar skor item instrumen dalam suatu faktor dan mengkorelasikan antara skor faktor dan skor total. Untuk mengukur validitas instrument maka digunakan rumus korelasi product moment. Uji realibilitas instrument kemampuan membaca permulaan yang digunakan dalam penelitian ini yaitu menggunakan rumus Alpha Cronbach. Setelah data dalam penelitian ini terkumpul, maka selanjutnya dilakukan analisis data.

Analisis data yang digunakan adalah metode analisis statistik deskriptif dan data dianalisis dengan menghitung mean, median, modus, standar deviasi, varians, skor maksimum dan skor minimum. Untuk uji normalitas data digunakan uji Chi-Square (x2) pada taraf signifikan 5\% dan derajat kebebasan $\mathrm{dk}=(\mathrm{k}-2-1)$. Sedangkan teknik yang digunakan untuk menganalisis data guna menguji hipoteis penelitian adalah uji-t. Salah satu prasyarat yang harus dipenuhi dalam uji-t adalah varian dalam kelompok harus normal dan homogen. Untuk dapat membuktikan dan memenuhi prasyarat tersebut maka dilakukan uji prasyarat analisis dengan melakukan uji homogenitas dan uji normalitas. Kriteria pengujian, jika $F_{\text {hit }}<F_{\text {tab }}$ maka kedua kelompok homogen sebaliknya jika $F_{\text {hit }} \geq$ $F_{\alpha}(n 1-1, n 2-1)$ pada taraf signifikan $5 \%$ dengan derajat kebebasan untuk pembilang $n 1-1$ dan derajat kebebasan untuk penyebut $\mathrm{n} 2-1$, maka $\mathrm{H}_{0}$ ditolak yang berarti sampel tidak homogen. Pada penelitian ini akan diuji perbedaan variabel terikat yakni kemampuan membaca permulaan antara kelompok eksperimen dan kelompok kontrol. Metode analisis data yang digunakan untuk menguji hipotesis adalah uji-t Polled varians.

\section{HASIL DAN PEMBAHASAN}

Data mengenai hasil skor membaca permulaan anak yang diperoleh dari hasil pre-test dan posttest yang diberikan pada kelompok eksperimen dan kontrol. Rangkuman hasil analisis data deskriptif 
data kemampuan membaca permulaan pada kelompok eksperimen dan kelompok kontrol disajikan pada Tabel 1.

Tabel 1.

Deskriptif Data Analisis Kelompok Eksperimen

\begin{tabular}{llcccc}
\hline Eksperimen & $\mathrm{N}$ & $\mathrm{M}$ & Me & Mo & SD \\
\hline Pre-test & 20 & 31,75 & 31,15 & 30,73 & 3,66 \\
Post-test & 20 & 55,75 & 56,98 & 57,58 & 3,72 \\
\hline
\end{tabular}

Tabel 2.

Deskriptif Data Analisis Kelompok Kontrol

\begin{tabular}{lccccc}
\hline Kontrol & $\mathrm{N}$ & $\mathrm{M}$ & Me & Mo & SD \\
\hline Pre-test & 15 & 28,39 & 26,86 & 25,6 & 4,35 \\
Post-test & 15 & 31,18 & 29,26 & 28,54 & 4,32 \\
\hline
\end{tabular}

Sebelum melakukan uji hipotesis maka harus dilakukan beberapa uji prasyarat terhadap sebaran data yang meliputi uji normalitas dan uji homogenitas. Uji asumsi dilakukan sebelum uji hipotesis. Uji asumsi dalam penelitian ini meliputi uji normalitas dan uji homogenitas hasil kemampuan membaca permulaan anak. Uji normalitas sebaran data dimaksudkan untuk memperlihatkan bahwa data sampel benar-benar berasal dari populasi yang berdistribusi normal, sehingga uji hipotesis dapat dilakukan. Uji normalitas data pada penelitian ini menggunakan uji normalitas dengan teknik Chi-Square $(x 2)$. Hasil perhitungan normalitas sebaran data menggunakan uji statistik Chi-Square $(x 2)$ pada kelompok eksperimen dapat dilihat pada Tabel 2.

Tabel 3.

Rangkuman Hasil Uji Normalitas Sebaran Data Post-test Kelompok Eksperimen

\begin{tabular}{cccc}
\hline Kelompok & $\mathrm{x}^{2}$ hitung & $\mathrm{x}^{2}$ tabel & Normalitas \\
\hline Eksperimen & 8,89 & 11,07 & Normal \\
\hline
\end{tabular}

Tabel 4.

Rangkuman Hasil Uji Normalitas Sebaran Data Post-test Kelompok Kontrol

\begin{tabular}{cccc}
\hline Kelompok & $\mathrm{x}^{2}$ hitung & $\mathrm{x}^{2}$ tabel & Normalitas \\
\hline Kontrol & 4,63 & 11,07 & Normal \\
\hline
\end{tabular}

Berdasarkan hasil uji di atas diperoleh bahwa Chi-Square hitung < Chi-Square tabel, maka dapat disimpulkan bahwa sebaran data post-test pada kelompok eksperimen dan kelompok kontrol berdistribusi normal.

Selanjutnya uji homogenitas dilakukan antar kelompok digunakan untuk mengukur apakah sebuah kelompok data mempunyai varian yang homogen. Kriteria pengujian, jika Fhitung > Ftabel, maka sampel tidak homogen. Jika $F_{\text {hitung }} \leq F_{\text {tabel }}$ maka sampel homogen. Pengujian dilakukan pada taraf signifikansi $5 \%$ dengan dk pembilang $n_{1}-1$ dan dk penyebut $n_{2}-1$. Berdasarkan analisis deskriptif, telah diperoleh nilai Standar Deviasi (SD) dan Varians dari pre-test kelompok eksperimen dan kelompok kontrol dapat dilihat pada Tabel 3.

Tabel 5.

Standar Deviasi dan Varians Pre-test Kelompok Eksperimen dan Kelompok Kontrol

\begin{tabular}{llll} 
Statistik & $\begin{array}{c}\text { Kelompok } \\
\text { Eksperimen }\end{array}$ & Kelompok Kontrol & Fhitung \\
\hline
\end{tabular}

\begin{tabular}{ccc}
\hline Standar Deviasi & 3,66 & 4,35 \\
\hline Varians & 13,39 & 18,92 \\
\hline $\mathrm{N}$ & 20 & 15
\end{tabular}


Berdasarkan perhitungan uji homogenitas dengan uji Fisher (uji F) diperoleh Fhitung $=1,41$ dan Ftabel dengan dk pembilang $(15-1=14)$ dan dk penyebut $(20-1=19)$ dengan taraf signifikan $5 \%=$ 4,14. Dengan demikian Fhitung $<$ Ftabel $=1,41<4,14$, sehingga kedua kelompok data dikategorikan homogen.

Tabel 6.

Standar Deviasi dan Varians Post-test Kelompok Eksperimen dan Kelompok Kontrol

\section{Statistik \\ Kelompok \\ Eksperimen \\ Kelompok Kontrol \\ Fhitung}

\begin{tabular}{ccc}
\hline Standar Deviasi & 3,72 & 4,32 \\
\hline Varians & 13,83 & 18,66 \\
\hline $\mathrm{N}$ & 20 & 15
\end{tabular}

Berdasarkan perhitungan uji homogenitas dengan uji Fisher (uji F) diperoleh Fhitung $=1,34$ dan Ftabel dengan dk pembilang $(15-1=14)$ dan dk penyebut $(20-1=19)$ dengan taraf signifikan $5 \%=$ 4,14. Dengan demikian $F_{\text {hitung }}<F_{\text {tabel }}=1,34<4,14$, sehingga kedua kelompok data dikategorikan homogen.

Lebih jelasnya, hasil perhitungan uji homogenitas dapat dilihat pada Tabel 7.

Tabel 7.

\begin{tabular}{ccccc}
\multicolumn{8}{c}{ Rekapitulasi Hasil Perhitungan Uji Homogenitas } & \\
Kelompok & Varians & F hitung & F tabel & Kesimpulan \\
\hline Pre-test Eksperimen & 13,39 & 1,41 & 4,14 & Homogen \\
\cline { 1 - 2 } Pre-test Kontrol & 18,92 & & & \\
\hline Post-test Eksperimen & 13,83 & 1,34 & 4,14 & Homogen \\
\cline { 1 - 2 } Post-test Kontrol & 18,66 & & &
\end{tabular}

Berdasarkan hasil uji prasyarat, yaitu uji normalitas dan uji homogenitas varians dapat disimpulkan bahwa data dari semua kelompok berdistribusi normal dan varians kedua kelompok homogeny. Dengan demikian uji hipotesis dengan uji-t dapat dilanjutkan.

Berdasarkan uji prasyarat yang dilakukan yaitu uji normalitas dan uji homogenitas, diperoleh bahwa data hasil kemampuan membaca permulaan anak kelompok eksperimen dan kelompok kontrol adalah normal dan homogen. Dengan demikian dapat dilakukan uji hipotesis penelitian dengan rumus uji-t polled varians, karena jumlah sampel berbeda dan varian homogen. Kriteria untuk pengujian hipotesis adalah $\mathrm{H}_{0}$ diterima jika $\mathrm{t}_{\text {hitung }} \leq \mathrm{t}_{\text {tabel }}$ dan $\mathrm{H}_{0}$ ditolak jika $t_{\text {hitung }} \geq t_{\text {tabel. }}$. Pengujian dilakukan pada taraf signifikansi $5 \%$ dengan $\mathrm{dk}=\mathrm{n}_{1}+\mathrm{n}_{2}-2$. Hipotesis penelitian yang diajukan yaitu sebagai berikut terdapat pengaruh yang signifikan terhadap kemampuan membaca permulaan anak yang diterapkan metode pembelajaran Struktural Analitik Sintetik (SAS) pada anak kelompok B di gugus IV Kecamatan Buleleng Kabupaten Buleleng tahun pelajaran 2018/2019. Untuk pengujian hipotesis penelitian dijabarkan menjadi hipotesis nol $\left(\mathrm{H}_{0}\right)$ melawan hipotesis alternative $\left(\mathrm{H}_{\mathrm{A}}\right)$. Rangkuman hasil uji hipotesis post-test kemampuan membaca permulaan anak pada kelompok eksperimen dan kelompok kontrol dapat dilihat pada Tabel 8.

Tabel 8.

Rangkuman Hasil Uji Hipotesis Post-Test Kelompok Eksperimen Dan Kontrol

\begin{tabular}{|c|c|c|c|c|c|c|c|c|}
\hline No & Kelompok & $\mathrm{N}$ & $\mathrm{dk}$ & $\mathrm{M}$ & Varians & t hitung & $\mathrm{t}$ tabel & Keterangan \\
\hline 1 & Eksperimen & 20 & 33 & 55,75 & 13,83 & 18,74 & 2,034 & $\mathrm{H}_{0}$ ditolak, \\
\hline 2 & Kontrol & 15 & & 31,18 & 18,66 & & & $\mathrm{H}_{\mathrm{A}}$ diterima \\
\hline
\end{tabular}

Berdasarkan analisis data menggunakan uji-t, diperoleh thitung $=18,74$ dan ttabel dengan $\mathrm{dk}=$ $(n 1+n 2-2)=33$ dengan taraf signifikansi $5 \%=2,034$. Dengan demikian $t_{\text {hitung }}>t_{\text {tabel }}=18,74>$ 2,034, maka $\mathrm{H}_{0}$ ditolak dan $\mathrm{H}_{\mathrm{A}}$ diterima. Jadi, dapat disimpulkan bahwa terdapat pengaruh yang 
signifikan terhadap kemampuan membaca permulaan anak sebelum dan sesudah mendapatkan metode Struktural Analitik Sintetik (SAS).

Metode Struktural Analitik Sintetik (SAS) berpengaruh secara signifikan terhadap kemampuan membaca permulaan anak. Hasil temuan pada kelompok yang awalnya memiliki kemampuan setara, yang kemudia di berikan perlakuan pada kelompok eksperimen maka diperoleh kemampuan membaca permulaan mengalami perbedaan yang signifikan. Kemampuan membaca permulaan pada kelompok eksperimen lebih baik dibandingkan dengan kemampuan membaca permulaan pada kelompok kontrol, hal ini dapat dilihat juga dari nilai $t_{\text {hitung }}$ lebih besar dibandingkan dengan nilai $t_{\text {tabel }}$, yaitu $=18,74>2,034$. Perbedaan kemampuan membaca permulaan disebabkan oleh perlakuan berupa metode Struktural Analitik Sintetik (SAS) yang diterapkan di kelompok eksperimen.

Metode Struktural Analitik Sintetik (SAS) memanfaatkan gambar, benda nyata atau tanya jawab dengan anak menjadikan interaksi-interaksi menjadi lebih bermakna, sehingga anak lebih mudah untuk meningkatkan kemampuan membaca permulaan. Metode pembelajaran Struktural Analitik Sintetik (SAS) membuat anak untuk belajar dengan menggunakan metode ini dalam kegiatan pembelajaran dapat memberikan gambaran untuk mendalami materi yang dibelajarkan dengan cara berkesan sehingga anak dapat dengan mudah dan cepat mengkaji permasalahan dengan situasi belajar yang menyenangkan serta melalui kegiatan yang menarik dan media yang menarik membuat anak tertarik dalam belajar. Pada prinsipnya metode ini menggunakan prinsip lingustik (ilmu bahasa) yang memandang satuan bahasa terkecil untuk berkomunikasi adalah kalimat. Hal ini didukung oleh ahli bahasa terkenal Noam Chomsky (Santrock, 2004:69) mengatakan bahwa "manusia cenderung mempelajari bahasa pada waktu tertentu dan dengan cara tertentu". Kemajuan dalam bahasa di masa kanak-kanak akan memberikan dasar bagi perkembangan selanjutnya pada usia sekolah dasar.

Berbeda dengan temuan yang diperoleh pada anak kelompok eksperimen, pada kelompok kontrol yang memusatkan pembelajaran kepada guru. Peran guru selama kegiatan yaitu menyampaikan tema yang dibahas selama pembelajaran adalah alam semesta. Pada awal kegiatan guru melakukan apersepsi dengan mengingat kembali materi sebelumnya dan menanyakan hal-hal yang berkaitan dengan kehidupan anak. Setelah anak-anak menjawab, selanjutnya guru mengaitkan jawaban anak dengan tema yang akan dibahas. Kegiatan tersebut membuat anak merasa jenuh, sebab anak dituntut untuk belajar dengan cara mengingat. Anak dilibatkan dalam awal penjelasan namun guru melihat hasil pekerjaan anak tanpa menanyakan apakah anak sudah memahami kegiatan dan apa yang diperoleh anak dari kegiatan tersebut. Kegiatan yang menyamaratakan kemampuan anak menyebabkan motivasi belajar anak menjadi rendah, karena anak yang memang sedari awal berkembang dengan baik akan melampaui jauh anak yang mengalami kesulitan. Hal ini berdampak pada rendahnya nilai kemampuan membaca permulaan anak.

Selain itu, melalui metode Struktural Analitik Sintetik (SAS) juga mampu meningkatkan kepercayaan diri, kemampuan sosial pada anak. Hal ini tampak ketika ada beberapa anak yang pasif saat pertemuan pertama karena tidak terbiasa membaca di depan teman-temannya secara mandiri, saat melihat teman-temannya yang lain sangat menikmati terlihat menyenangkan, pada pertemuan selanjutnya menjadi percaya diri untuk mulai berani membaca di depan teman-temannya secara mandiri. Kemampuan sosial anak juga tampak meningkat melalui metode pembelajaran ini, terlihat pada saat anak berinteraksi bermain kartu huruf dan saling bertukaran kartu dengan teman yang lainnya. Metode pembelajaran ini akan dapat memberikan kesan pembelajaran menjadi lebih bermakna dan menyenangkan. Timbulnya rasa senang terhadap pembelajaran akan mempengaruhi hasil perkembangan bahasa anak yang ingin dicapai dalam hal ini kemampuan membaca permulaan. Terlebih lagi jika pembelajaran dengan metode ini pembelajaran akan lebih menantang keterlibatan anak dalam pembelajaran.

Hasil penelitian ini sejalan dengan hasil penelitian sebelumnya yang dilakukan oleh Kurniaman \& Eddy (2017), Dalam penelitian ini pembelajaran dengan menggunakan metode struktural analitik sintetik (SAS) pada kemampuan membaca permulaan di kelas 1 SD di SDN 79 Pekanbaru lebih efektif dibandingkan dengan pembelajaran menggunakan metode konvensional. Hal ini terbukti adanya peningkatan nilai pada kelas eksperimen lebih besar dibandingkan dengan kelas kontrol. Data hasil postest kelas eksperimen dengan rata-rata 84,33 sedangkan kelas control dengan rata- 
rata 79,50 dengan hasil uji statistik maka terdapat perbedaan perbedaan yang signifikan antara kelas control dan kelas eksperimen. Selain itu penelitian yang dilakukan oleh Prastiwi, dkk (2013) dengan hasil penelitian menunjukan bahwa kemampuan mengenal membaca dan menulis permulaan meningkat dengan menggunakan metode Struktural Analitik Sintetik (SAS) pada siswa kelompok B2 TK N Pembina Cawas dengan melihat nilai rata-rata ketuntasan pada kondisi awal hanya $34,6 \%$, siklus I $53,8 \%$ dan siklus II meningkat menjadi $92,3 \%$. Berdasarkan hasil perhitungan tersebut terbukti bahwa metode Struktural Analitik Sintetik (SAS) berpengaruh yang signifikan terhadap kemampuan membaca permulaan pada anak.

Berdasarkan paparan tersebut bahwa metode Struktural Analitik Sintetik (SAS) tepat dijadikan sebagai salah satu alternative metode pembelajaran untuk menstimulasi kemampuan membaca permulaan. Melalui metode Struktural Analitik Sintetik (SAS) dapat memberikan kesan pembelajaran lebih bermakna dan menyenangkan serta dilaksanakan secara bertahap dan tidak menyimpang dari dunia dan kebutuhan anak. Penggunaan metode SAS dalam pembelajaran membaca permulaan di Taman Kanak-kanak merupakan salah satu alternatif dalam membantu atau membimbing anak ke arah penemuan sendiri dalam pengajaran membaca permulaan pada anak usia dini dimana metode ini ditampilkan struktur kalimat secara utuh, kemudian dianalisis menjadi kata, suku kata dan huruf dengan menggunakan bantuan alat peraga/media yang menarik dan inovatif untuk anak. Terlebih lagi jika pembelajaran dengan metode SAS pembelajaran akan lebih menantang keterlibatan anak dalam pembelajaran. Jadi, tampak jelas bahwa metode Struktural Analitik Sintetik (SAS) berpengaruh terhadap kemampuan membaca permulaan pada anak kelompok B Taman Kanakkanak Gugus IV Kecamatan Buleleng tahun pelajaran 2018/2019.

Hasil penelitian ini merupakan pengembangan metode pembelajaran Struktural Analitik Sintetik (SAS) untuk mengembangkan kemampuan membaca permulaan anak, dimana kemampuan membaca permulaan adalah kemampuan yang lebih menekankan pada pengenalan lambanglambang bunyi dan rangkaian huruf kemudian menghubungkan dengan makna yang terdapat dalam rangkaian huruf (Braja dalam Laely, 2013). Kemampuan membaca permulaan anak dalam penelitian ini adalah kemampuan yang ditinjau berdasarkan indikator dan komponen kemampuan membaca permulaan anak meliputi: mengenal lambang dan bunyi huruf, menggabungkan huruf dan bunyi huruf menjadi suku kata dan kata serta mengucapkan kalimat sederhana. Metode pembelajaran Struktural Analitik Sintetik (SAS) di TK Cudhacrama Singaraja memberikan dampak positif di dalam lingkungan sekolah. Adanya dampak positif dari hasil skor kelompok eksperimen diartikan penelitian ini dapat digeneralisasikan diterapkan di tempat yang memiliki masalah dan karakteristik yang sama dengan digunakan perlakuan sebagaimana pada kelompok eksperimen.

Diharapkan kedepannya hasil penelitian ini dapat menjadi kebijakan nasional, karena kemampuan membaca permulaan anak tidak dapat dipandang sebelah mata, anak memerlukan kemampuan membaca permulaan ini untuk menyalurkan huruf, suku kata, kata dan kalimat yang disajikan dalam bentuk tulisan ke dalam bentuk lisan. Oleh sebab itu perlu adanya upaya untuk meningkatkan kemampuan membaca permulaan anak. Metode Struktural Analitik Sintetik (SAS) mampu menjadi alternative untuk meningkatkan kemampuan membaca permulaan yang ada pada anak, sehingga diharapkan kedepannya metode pembelajaran Struktural Analitik Sintetik (SAS) selalu direvitalisasikan agar dapat dijadikan treatment untuk meningkatkan kemampuan membaca permulaan anak disekolah. Sehingga hasil penelitian ini dapat dijadikan acuan dalam meningkatkan kemampuan membaca permulaan anak di gugus IV Kecamatan Buleleng Kabupaten Buleleng.

\section{PENUTUP}

Penelitian ini dilakukan di gugus IV Kecamatan Buleleng Kabupaten Buleleng dengan jenis penelitian eksperimen semu (quasi experiment) dengan rancangan non-equievalent control group design. Pemilihan kelompok eksperimen dan kelompok kontrol dilakukan dengan menggunakan teknik simple random sampling. Sehingga dipilihnya kelompok B2 Taman Kanak-kanak Cudhacrama Singaraja sebagai kelompok eksperimen dan kelompok B2 Taman Kanak-kanak Santi Kumara Singaraja sebagai kelompok kontrol. Metode pengumpulan data yang dilakukan dalam penelitian ini menggunakan metode observasi dan wawancara. Uji coba instrument pada penelitian ini menggunakan uji validitas isi. Uji validitas isi menggunakan tabulasi silang dua pakar dan uji validitas butir dengan rumus korelasi product moment. Dalam menganalisis data dilakukan dengan 
menggunakan metode analisis statistik deskriptif yang bertujuan untuk mengetahui tinggi rendahnya data. Uji asumsi data yang terdiri dari uji normalitas menggunakan Chi-square dan uji homogenitas menggunakan uji Fisher $(F)$. Dimana data kedua kelompok berdistribusi normal dan homogeny. Uji hipotesis menggunakan uji-t polled varians, dimana hasil uji hipotesis post-test kelompok eksperimen dan post-test kelompok kontrol adalah terdapat pengaruh yang signifikan terhadap kemampuan membaca permulaan kelompok eksperimen dan kelompok kontrol (thitung ttabel = 18,74 2,034), hal ini berarti metode Struktural Analitik Sintetik (SAS) berpengaruh terhadap kemampuan membaca permulaan pada anak kelompok B di gugus IV Kecamatan Buleleng Kabupaten Buleleng.

Berdasarkan paparan hasil penelitian dan pembahasan maka dapat disimpulkan bahwa terdapat pengaruh yang signifikan metode Struktural Analitik Sintetik (SAS) terhadap kemampuan membaca permulaan anak, hal ini berarti pembelajaran metode Struktural Analitik Sintetik (SAS) berpengaruh terhadap kemampuan membaca permulaan pada anak kelompok B di gugus IV Kecamatan Buleleng Kabupaten Buleleng tahun pelajaran 2018/2019. Hal ini terlihat dari hasil pengujian hipotesis dengan menggunakan uji-t polles varians dengan diperoleh $t_{\text {hitung }}$ adalah 18,74 dan $t_{\text {tabel }}$ dengan taraf signifikan $5 \%$ dan derajat kebebasan 33 adalah 2,034. Karena $t_{\text {hitung }}>t_{\text {tabel }}$ maka $\mathrm{H}_{\mathrm{A}}$ yaitu terdapat perbedaan yang signifikan terhadap kemampuan membaca permulaan anak kelompok eksperimen dan kelompok kontrol, hal ini berarti metode Struktural Analitik Sintetik (SAS) berpengaruh terhadap kemampuan membaca permulaan pada anak kelompok B di gugus IV Kecamatan Buleleng Kabupaten Buleleng tahun pelajaran 2018/2019. Hal ini dapat diartikan bahwa metode Struktural Analitik Sintetik (SAS) mampu memotivasi minat belajar anak untuk meningkatkan kemampuan membacanya. Dengan adanya pengaruh yang signifikan antara kelompok eksperimen dan kelompok kontrol, dapat diartikan bahwa metode metode Struktural Analitik Sintetik (SAS) dapat dijadikan alternatif pembelajaran untuk meningkatkan kemampuan membaca permulaan anak usia dini.

\section{DAFTAR PUSTAKA}

Agung, A.A. Gede. 2014. Metodologi Penelitian Pendidikan. Singaraja: Universitas Pendidikan Ganesha.

Aida, Siti. 2018. "Meningkatkan Keterampilan Membaca Awal Melalui Metode Struktural Analitik Sintetik Dengan Menggunakan Media Audio Visual”. Jurnal IImiah Potensia Volume 3 (1), (hlm. 56-63).

Ambara, Didith Pramunditya, dkk. 2014. Asesmen Anak Usia Dini. Yogyakarta: Graha Ilmu.

Candiasa, I.M. 2011. Pengujian Instrumen Penelitian Disertai Aplikasi ITEMAN dan BIGSTEPS. Singaraja: Unit Penerbit Universitas Pendidikan Ganesha.

Jahja, Yudrik. 2011. Psikologi Perkembangan. Jakarta: Kencana.

Kurniasih \& Berlin. 2015. Ragam Pengembangan Model Pembelajaran Untuk Peningkatan Profesionalitas Guru. Jakarta: Kata Pena.

Kurniawan \& Eddy. 2017. "Metode Membaca SAS (Struktural Analitik Sintetik) Dalam Meningkatkan Keterampilan Membaca Permulaan Di Kelas 1 SDN 79 Pekanbaru". Volume 05 Nomor 02 ISSN: 2303-1514).

Laely, Khusnul. 2013. "Peningkatan Kemampuan Membaca Permulaan Melalui Penerapan Media Kartu Gambar". Jurnal Pendidikan Anak Usia Dini, Volume7 Edisi 2.

Mutiah, Diana. 2010. Psikologi Bermain Anak Usia Dini. Jakarta: Kencana Prenada Media Group.

Pertiwi, Adharina Dian. 2016. "Study Deskriptif Proses Membaca Permulaan Anak Usia Dini. Jurnal Pendidikan Anak, Volume 5, Edisi 1.

Prastiwi, dkk. 2013. "Penerapan Metode Struktural Analitik Sintetik (SAS) Untuk Meningkatkan Kemampuan Mengenal Membaca dan Menulis Permulaan Untuk Anak Usia Dini di TK N Pembina Cawas Kelompok B Tahun Pelajaran 2011/2012". Volume 01 Nomor 1. Papalia, D.E, dkk. 2008. Human Development (Psikologi Perkembangan). New York: McGraw Hill Companies.

Sani, Ridwan Abdullah. 2014. Inovasi Pembelajaran. Jakarta: PT Bumi Aksara.

Santrock, John W. 2007. Perkembangan Anak. Jakarta: Erlangga

Sugiyonno. 2017. Statistika Untuk Penelitian. Bandung: Alfabeta. 
Sugiyono, 2014. Metode Penelitian Pendidikan. Bandung: Alfabeta.

Sujiono, Yuliani Nurani. 2009. Konsep Dasar Pendidikan Anak Usia Dini. Jakarta: Kencana Media Group.

Susanto, Ahmad. 2011. Perkembangan Anak Usia Dini (Pengantar dalam Berbagai Aspeknya). Jakarta: Kencana Prenada Media Group.

Tjoe, Jo Lioe. 2013. "Peningkatan Kemampuan Membaca Permulaan Melalui Pemanfaatan Multimedia (Action Research, Kelompok B TK. Kristen Anugerah Jakarta, Tahun 2012). Jurnal Pendidikan Anak Usia Dini. Volume 7, Edisi 1. 